\title{
The life cycle of a free newspaper business model in newspaper-rich markets
}

BY PIET BAKKER

\begin{abstract}
Free newspapers may offer different news contents to different audiences, when compared with traditional, paid-for newspapers, but they, nevertheless, concentrate on news, and thereby provide society with information on current affairs. These papers have seen circulation rise until 2008; after that, a decline set in, leading to closures and often a monopoly situation in the mature European newspaper markets covered in our research. Free newspapers seem to follow a typical life cycle pattern, moving from growth to maturity, and to saturation and decline. Diversification strategies - home-delivery, weekend, sports, afternoon, and financial - have been disappointing so far. There is no evidence, however, of total extinction, indicating that there is room for at least one title - possibly two - in every market. The situation in the surveyed markets also suggests that a free newspaper may be a 'natural' monopoly.
\end{abstract}

\section{Introduction}

For more than a decade, the dominant discourse on the future of newspapers is one of decline, and how to overcome, counter or deal with this unavoidable predicament. Philip Meyer predicted in The Vanishing Newspaper (2004) that no American 
would read a newspaper on a daily basis in 2043, if the current decline would persist. Meyer urged publishers to invest in local reporting, to strengthen the position of the newspaper, instead of a 'harvesting' strategy that would, in the long run, prove to be fatal. Newspaper publishers, however, were faced with the threat of digital media, and chose to invest in online platforms, pay walls, tablet-newspapers and mobile services.

Apart from this digital switch, publishers also innovated their print product by launching new editions, switching to a smaller format or introducing new feature sections and magazines. By far the most successful innovation - leading to an increase in circulation in many countries instead of a decline - was the free daily newspaper. Since the economic crisis of 2008, this model has been under severe pressure. After years of permanent and spectacular growth, the free newspaper market is showing signs of maturity, saturation and decline. As the business of free newspapers solely depends on advertising, the recession has hit this business very hard, leading to closures and cuts in circulation. This begs the question, how sustainable this model is. Are free newspapers a passing phenomenon that only had a short-time impact, or is it a specific product that found its niche after the first wave of launches and closures?

\section{Theory}

We will track this development in the European markets, where newspapers were always the dominant news medium, were journalism developed into a professional occupation, and where newspaper publishers operate independent, commercial newspapers targeted on a mass audience. Hallin and Mancini (2004) call these markets 'democratic corporatist' and liberal. These models are characterized by mass circulation newspapers and professional journalism, although they differ, where state intervention and political parallelism are concerned. In Europe, these countries can be found in the Nordic region (Iceland, Norway, Sweden, Finland, Denmark), in the Netherlands and Belgium, and in the German and English-speaking countries (UK, Ireland, Germany, Austria, Switzerland and Luxembourg). These 
countries - with the exception of Ireland - have a penetration of 25 newspaper copies or more per 100 inhabitants (Figure 1).

Figure 1. Paid and free newspaper penetration in Europe 2010 (sources: World Press Trends for paid papers, own research for free dailies)

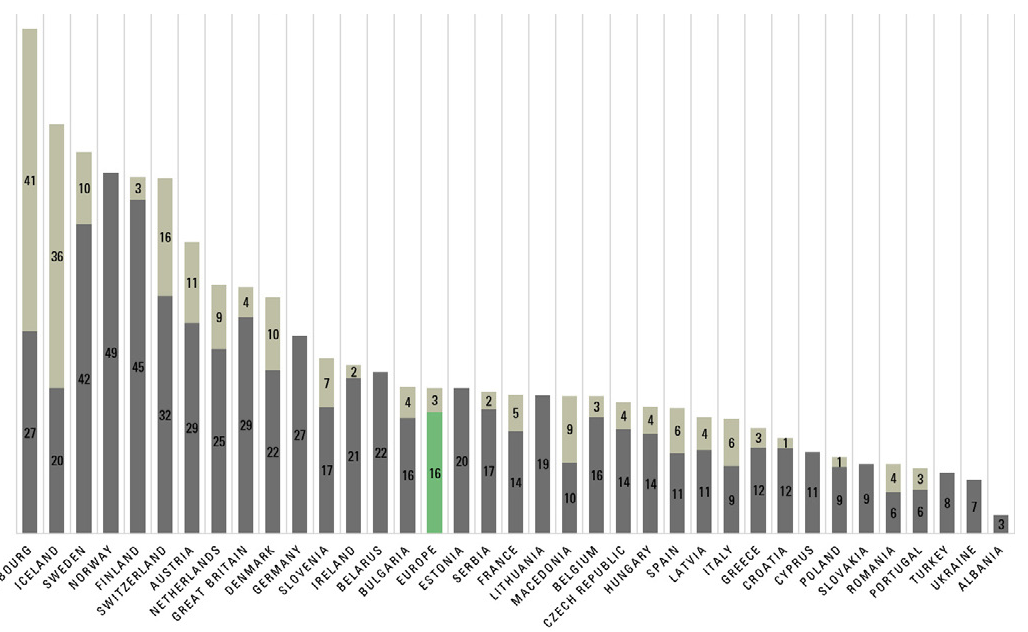

There has been some debate about the journalistic value of free newspapers, because they tend to offer only a small portion of original news, and focus more on entertainment than 'traditional' newspapers. Kammer (2009), however, showed that Danish free newspapers contain at least as much political news as tabloid newspapers (see also Hjarvard, 2007). Wadbring (2007) studied how different social groups in Gothenburg used free and paid newspapers, and found that underprivileged groups, who would normally not have access to newspapers, actually read free newspapers now. Bakker (2007) analysed the readership of free dailies in several European countries, and disclosed a consistent pattern of a predominantly young audience for free newspapers. This means that these newspapers offer valuable news to audiences that - at least in part - do not access traditional newspapers. Whatever the value of the content of free newspapers might be; they still serve a purpose for their readers and society by providing information.

In this article, we concentrate on mature newspaper markets, where newspapers have been an established product for many 
years. As decline is setting almost everywhere, we ask if newspapers follow a classic life cycle pattern.

The classic s-shaped curve shows different stages of sales of a product (Figure 2). The stages are usually referred to as introduction (or development), growth, maturity and decline (Anderson \&Zeithaml, 1984; Tlale, Bright, Potgieter \& Xu, 2002; Keiningham, Vavra, Lerzan \& Wallard, 2005). Maturity is defined as declining growth, while during decline (or saturation) sales are going down (Connelly \& Daignault, 1974). Although the model has been criticized, because it does not seem to be applicable to every market, and because of some assumptions the model makes (see Klepper, 1996), it is still probably the most used model to map growth and decline of products. The model was originally developed to describe international trade (Vernon, 1966), and has often been applied to technological industries. Van Zuilen (1977) used the model for the American magazine market. Picard (2008, p. 12) suggests that the newspaper industry in total "seems to be following a basic industry life cycle pattern." In this article, we use the model to assess, which phase free newspapers find themselves in, in different markets.

Figure 2. Theoretical model of introduction, growth, maturity and saturation/ decline

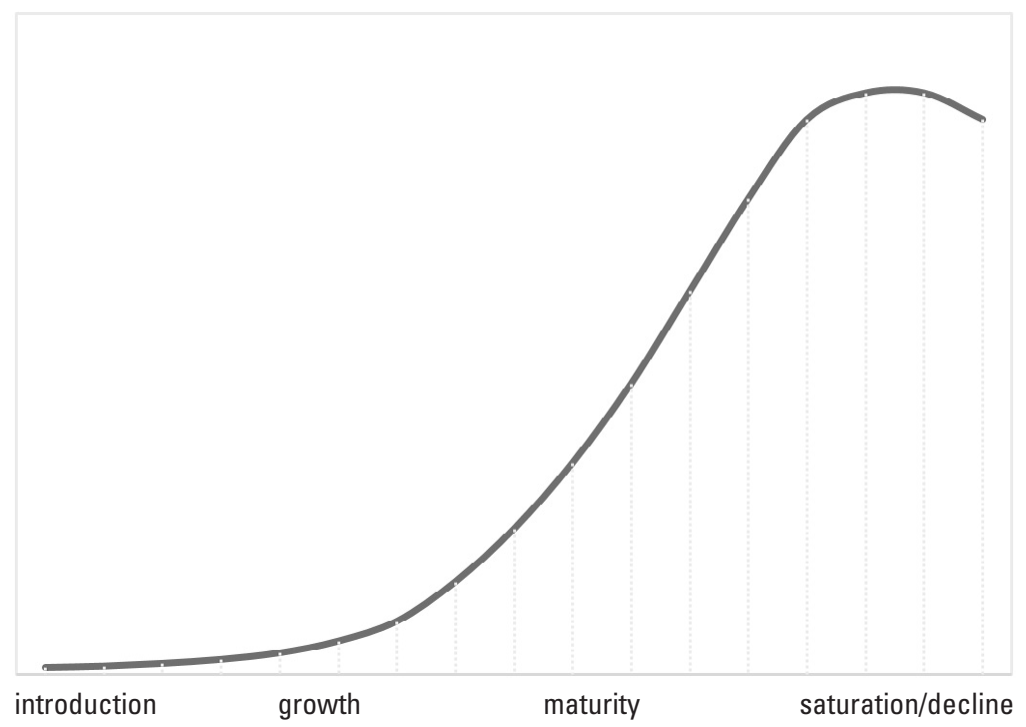


Free newspapers are not 'normal' products that follow a 'normal' introduction pattern in a market. Free dailies are introduced in mature newspaper markets with only a limited number of players, which, in many cases, led to fierce reactions from incumbent publishers. Incumbents launched spoiler products that offered advertising below normal rates; they tried to drive competitors from the market, or even prevented them from launching at all (Picard, 2001; Vogel, 2001; Bakker, 2002; Röper, 2006). Free newspapers sell no subscriptions or single copies, they only sell advertising. Although increasing sales may move technological and industrial products from one phase to another, the driving force behind a sudden increase in circulation of free newspapers is usually just the publisher. Nevertheless, consumers do have an indirect influence. Without convincing readership data, advertisers will not support the paper.

The 'end game' of a product like a free newspaper might be closure or consolidation, the result could be that very few or only one title remains. This could mean that free newspapers resemble a natural monopoly (see Lacy \& Picard, 1990; Picard, 1997). Usually, natural monopolies are associated with high entry costs and efficiencies in distribution infrastructure (railroads, electricity, water supply). In this case, the size of the (advertising) market and product similarity could explain the drive towards monopoly.

Diversification - moving away from the traditional model of the give-away public-transport morning paper might be a way out of this predicament. A 'regular', free, daily newspaper is published in the morning from Monday to Friday, is targeted at commuters and focuses on general news. In crowded markets, and also because incumbent publishers did not want to cannibalize their paid morning papers, different models have been developed. These fall within two broad categories: content diversification and distribution diversification. Business papers were launched in the UK, Ireland, Denmark, Switzerland and Germany. A sports paper was introduced in Germany. Another format is the free 'quality paper' which has been launched in Denmark, Iceland and the Netherlands - these models employ more journalists and usually have longer stories with more background information. 
Distribution diversification is a means to avoid competition or targeting special 'unique' audiences. As most free dailies are morning papers, the first obvious choice was to move it to the afternoon. Another option is publishing at weekends, which, so far, has been done with limited success. To avoid the competition of free commuter dailies, some papers moved to home-delivery. In Iceland, Switzerland, Denmark and the Netherlands, home delivery has been employed.

We will cover these different strategies below. When market size - audience, advertising - is too small, and costs of diversification are too high, exit strategies and consolidation might be the most obvious solutions.

\section{Data}

Circulation data for free newspapers are collected by the author from national auditing organizations, and in the remaining cases from various sources like business publications and the publishers themselves. For some years World Press Trends (20042011) provided data for some titles.

A free newspaper is defined as a publication with a frequency of at least four issues a week, and is available to the general public at no cost.

In the results sections, we will first cover Europe in general. After that, we will track the development of free dailies in four regions: the Nordic countries (Iceland, Sweden, Finland, Denmark), the Netherlands and Belgium, German-speaking countries (Germany, Austria, Switzerland and Luxembourg), and the UK and Ireland.

\section{Free newspapers in Europe}

In 1995, the first 'modern' free newspaper, Metro, was launched in the Swedish capital Stockholm (Larsson, 1996; Wadbring, 2003; Harrie, 2009). From 1997 on, Metro published in fourteen other European countries. The Norwegian media house Schibsted started free dailies in the period 1999-2001 in Switzerland, Ger- 
many, Spain and France. Also local entrepreneurs and incumbent publishers launched free dailies in almost every European country (Norway, Albania, Belarus, Cyprus and Slovakia being the only exceptions).

Until 2007, European free newspapers showed a permanent growth, sometimes even a spectacular growth (only in 1996, 2002, 2003 and 2007, it was below 25\%). The strongest growth showed between 1999 and 2001 (from 2.7 to 7.4 million) and between 2004 and 2007 (from 11 to 24 million). In 2007, growth dropped to $11 \%$. From 2008 on, circulation declined from 26 million to 15 million ( $10 \%$ per year on average).

Until 2007, the number of countries grew much slower than the number of titles. In 2000, 32 papers were published in 13 countries. In 2000, they counted 140 in 31 countries. Competition between free dailies increased - from two per country in 2000 to five in 2007 and 2008. Not all titles are published in the same markets, but metropolitan areas with three or more competing titles were not exceptional, as could be seen in London, Athens, Lisbon, Bucharest, and in most major markets in Denmark, Sweden, Switzerland, France, Spain, Italy and the Netherlands. A free daily monopoly was in fact quite rare. In 2012, the average number of titles per country is three, but as some of these papers are only published in regional markets, duopolies and monopolies are now much more common (Figure 3. Free Dailies in Europe 1995-2012 (source: own research)).

Figure 3. Free Dailies in Europe 1995-2012 (source: own research)

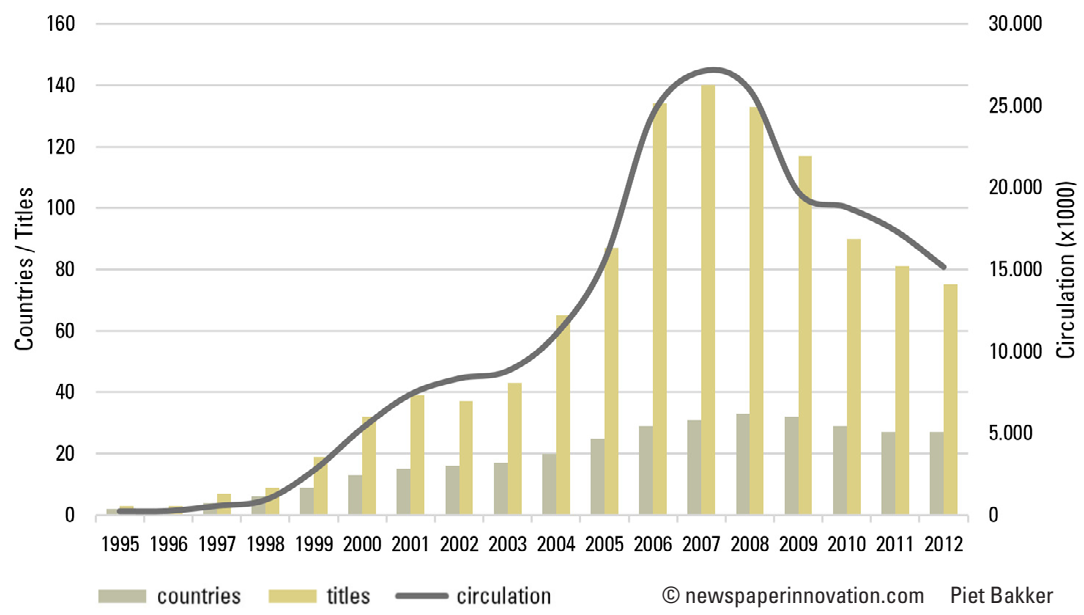




\section{Nordic countries}

All four Nordic countries with free dailies show a development from growth to decline. All were faced with fierce competition between 2004 and 2008. All of them have a free paper monopoly now.

Figure 4. Free dailies in the Nordic countries (source: own research)

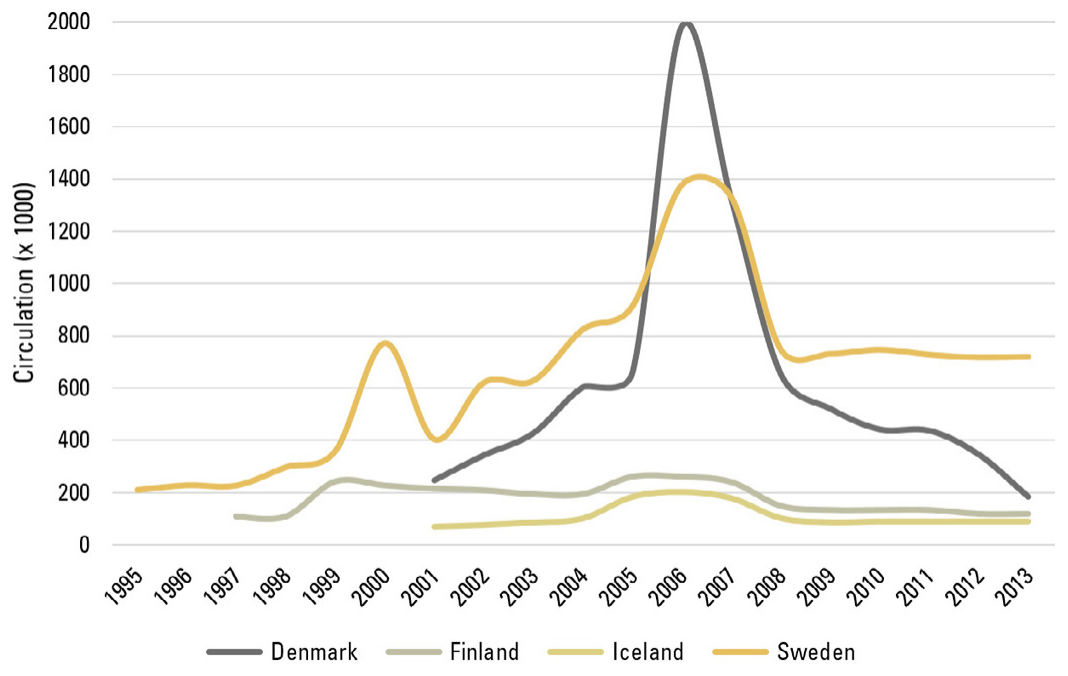

In Sweden, Metro launched in Stockholm in February 1995, in Gothenburg in 1998, and in Malmö in 1999. In 2004, a national edition was launched. In 2000, an entrepreneur launched an afternoon paper in Stockholm, which resulted in Metro launching an afternoon spoiler product. Both operations ended within one year. This explains the growth in 2000 and the decline one year later. In 2002, Bonnier, one of Metro's major competitors in Sweden (paid papers Dagens Nyheter and Expressen), launched their Stockholm City (later also with editions in Gothenburg and Malmö), while Schibsted, publisher of the leading paid paper Aftenbladet, launched Punkt SE in all three markets in 2006. In Sweden, free circulation increased by more than $50 \%$ between 2000 and 2006. City Gothenburg closed in 2007; City Stockholm converted into a non-daily one year later. Punkt SE closed in May 2008, after Schibsted acquired a stake in Metro Sweden. Metro is now the monopolist in Stockholm and Gothenburg; only in 
Malmö it competes with City. Local free papers are published in Norrköping and Upsala.

In the summer of 2006, Denmark was dragged into a newspaper war, after Icelandic publisher Dagsbrun announced they would launch Nyhedsavisen, a free home-delivered daily. Both JP/Politiken (24timer) and Berlingske Officin (Dato) reacted by launching free home-delivered papers themselves. Berlingske already launched their commuter free daily Urban as a response to MetroXpress in 2001. Dato closed down within one year, followed by local editions of the other free dailies and local free papers in Aalborg, Arhus and Odense. Circulation dropped by more than $30 \%$ in 2007 compared to the previous year. In 2008, circulation dropped again, now by more than $50 \%$ to less than 600,000 after the closure of Nyhedsavisen. In 2012, Urban closed down, while 24timer (acquired by Metro International in 2008) shut down in 2013. MetroXpress - now owned by Swiss publisher Tamedia - stayed as the only free daily. Diversification was not successful. Home-delivery was stopped altogether. An evening paper in Aalborg closed down, just like the Metro evening paper for Copenhagen. Quality paper Nyhedsavisen, publishing a Saturday edition, closed down as well.

In Iceland, free dailies had a market share of more than $80 \%$, until the economic recession hit the country in 2008. The success of Frettabladet (home delivered seven days a week) made another publisher launch competing free paper Bladid. The jump in circulation in 2005 started with this launch, although both papers show independent growth as well in 2006. In 2007, circulation was cut down, while in 2008, Bladid closed down, Frettabladet changed to six days a week.

In Finland, free daily Uutislehti 100 started in 1997, followed by a Metro edition two years later. Sanoma acquired Metro in 2006, and merged Uutislehti 100 and Metro in 2008, after the modest success of a diversification strategy.

\section{The Netherlands and Belgium}

The Netherlands showed a substantial growth until 2007, and a similar decline in the following years. Belgium has been a free 
Figure 5. Free dailies in the Netherlands and Belgium (source: own research)

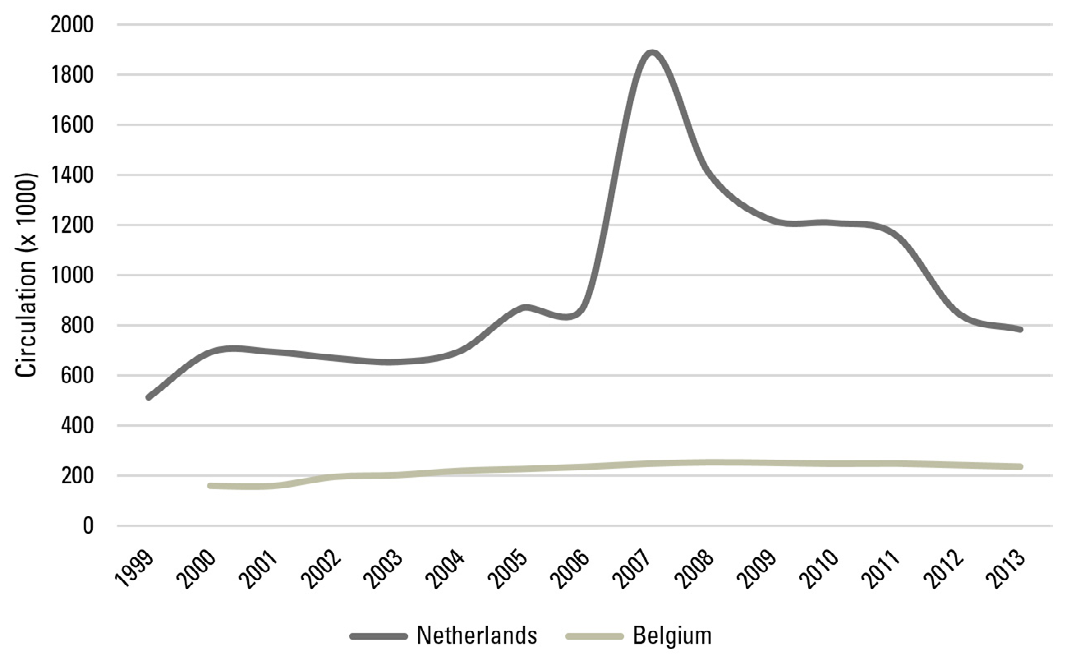

daily monopoly from the start (Figure 5. Free dailies in the Netherlands and Belgium (source: own research)).

Metro and Spits (by incumbent publisher De Telegraaf) launched on the same day in June 1999 in the Netherlands. Total circulation grew in 2000, after an afternoon paper was launched, and remained stable for three years: the afternoon paper folded, but both Metro and Spits increased circulation. In 2004 and 2005, circulation increased again because of the launch of local editions of Metro. In 2007, circulation more than doubled, when two new titles were launched. De Pers, trying to avoid competition by positioning itself as a quality product, with a bigger staff, longer stories and a weekend edition - part of the circulation was delivered direct to households. The second new entry, DAG, was an initiative by leading Dutch publisher PCM and telecom operator KPN. In 2008, DAG was closed down, whereas De Pers stopped their Saturday edition (Metro stopped a Saturday edition some years earlier), ended home-delivery and stopped altogether in 2012. Metro was sold to De Telegraaf in 2012; this publisher now owns both national free dailies in the country. The publisher lowered circulation, and integrated sales and editorial departments in 2013.

In Belgium, incumbent publishers Concentra (Belang van Limburg/Gazet van Antwerpen) together with Rossel (Le Soir) 
launched Metro in 2000; Concentra is still the majority owner. The paper, published in a French and a Dutch language edition, slowly increased circulation (from 160,000 to 250,000) until 2009.

\section{German-speaking countries}

Germany, by far the largest country in this group, was leading in free newspapers in 1998 and 1999; from that moment on, Switzerland had the highest circulation, while Austria has shown a growth in circulation over the last years. In Luxembourg, free dailies were introduced only in 2007 (Figure 6. Free dailies in Germany, Austria, Switzerland and Luxembourg (source: own research)).

Figure 6. Free dailies in Germany, Austria, Switzerland and Luxembourg (source: own research)

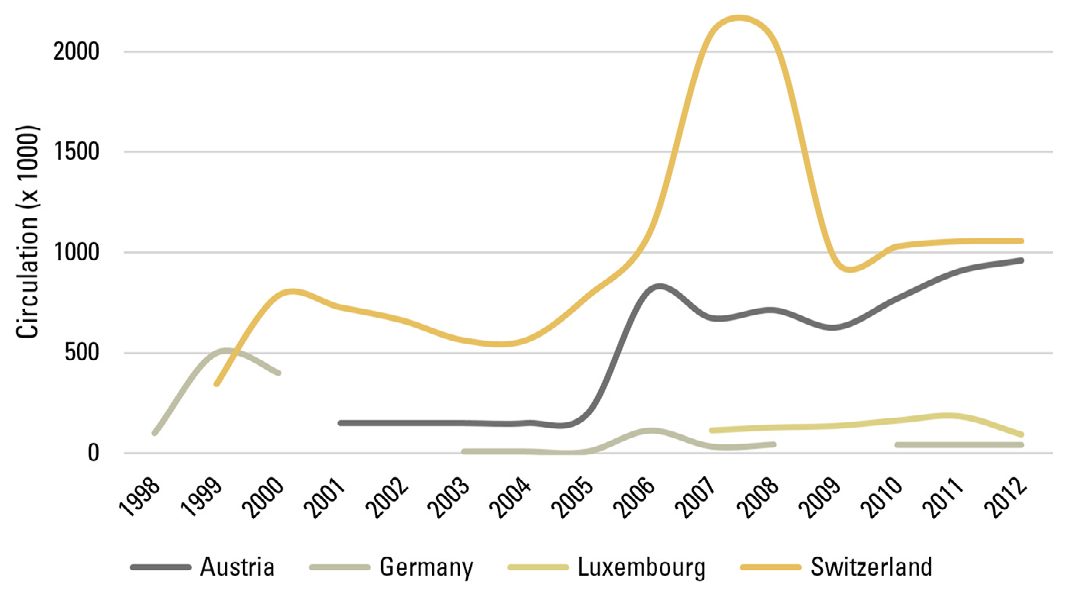

Germany was one of the first European countries where free dailies were introduced, starting with free afternoon paper 15 Uhr Aktuell in Hamburg, Berlin and Munich between 1998 and 2000. It was met by massive resistance from incumbent publishers. Germany was also the first country to see a genuine free newspaper 'war' (Vogel, 2001; Haas, 2006; Haller, 2009; Holznagel, 2006; Röper, 2006), when Schibsted and two incumbent publishers simultaneously launched free dailies in Cologne in December 1999. After several lawsuits, all three papers closed down in July 2001 - advertising rates were too low to support all 
three titles. Since that episode, no German publisher dared to launch a general free newspaper; all later free dailies (from 2003 on) have been business or sports papers, and were distributed in restricted areas, mostly to first-class passengers on airlines and trains.

Free daily 20 Minuten launched in Zurich in 1999. Between 2000 and 2007, the paper launched seven new editions, at first in German-speaking Switzerland, in 2006 and 2007 also in the French-speaking part (Prinzing, 2008). The launch of Metropol (Metro International) and a local free daily in Basle in 2000 resulted in a doubling of the Swiss circulation. Between 2000 and 2003, however, circulation dropped steadily, because Metropol closed down their editions. From 2005 on, circulation rose again, and new titles were launched each year. Geneva publisher Edipresse launched Le Matin Bleu, when 20 Minuten moved to the French-speaking part. Ringier, publisher of leading tabloid Blick, responded in 2006 with the business paper CASH daily and the afternoon free daily Heute - the latter was replaced by Blick am Abend in 2008. In 2007, two more free dailies were introduced: '.ch' by an independent entrepreneur, and News, a defensive move against '.ch' by Tamedia. In 2009, Le Matin Bleu, .ch and News closed down. German-speaking Switzerland is now a duopoly of Blick am Abend and 20 Minuten; the French-speaking part is a monopoly, while 20 Minuten also created a monopoly in the Italian-speaking part in 2011.

Austrian free circulation increased sharply in 2006, when free daily Heute increased circulation in Vienna, launched editions in other cities, and other local publishers reacted by starting free dailies in Graz, Klagenfurt, Linz and Innsbruck (Bakker \& Seethaler, 2009). In that same year, a new national paid paper was launched, Österreich, a substantial part of its circulation consisted of copies distributed for free. Between 2007 and 2009, three local free dailies folded, but as both remaining national models Heute and Österreich increased their circulation, total circulation in Austria also increased.

In Luxembourg, incumbent publisher Editpresse (paid paper Das Tageblatt) launched L'Essentiel (French language) in cooperation with Swiss publisher Tamedia (20 Minuten). Competitor Saint Paul (paid paper Luxemburger Wort) responded by a com- 
bined French/German edition of Point24 in 2011 - the publisher later experimented with separate German and French editions, an afternoon edition and a Portuguese edition for foreign workers, but eventually closed down the paper in 2012 .

\section{UK and Ireland}

Total circulation in the UK and Ireland increased from 300,000 in 1999 to 2.3 million in 2012. Ireland became a monopoly; in the UK, only London sees competition among free dailies (Figure 7. Free dailies in the UK and Ireland (source: own research)).

Figure 7. Free dailies in the UK and Ireland (source: own research)

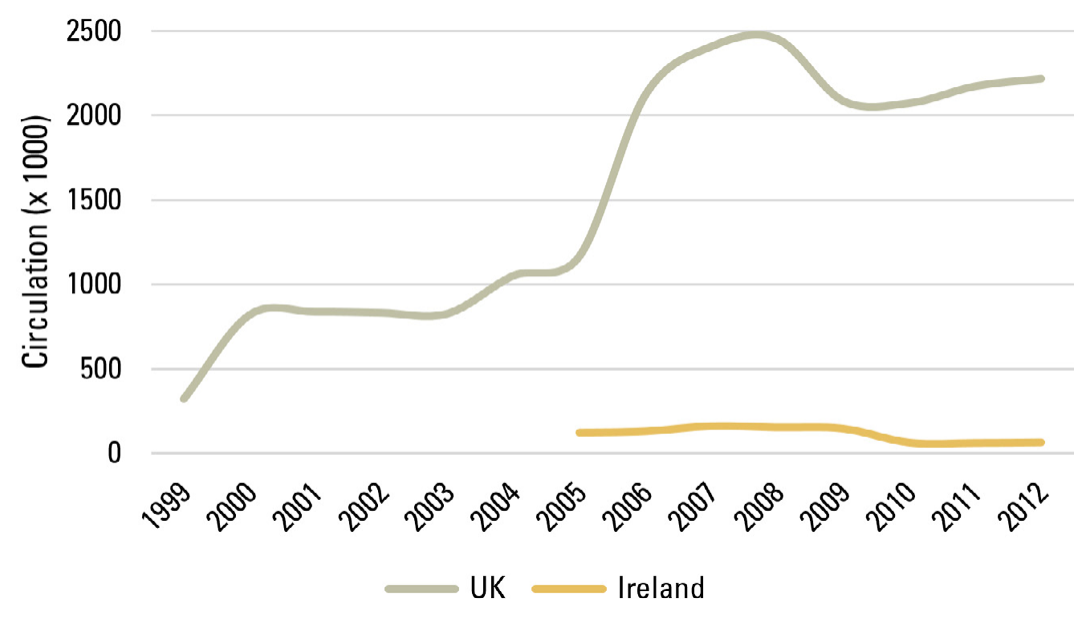

Also the UK was the scene of a newspaper war (Klausch, 2007). In the summer of 2006, Rupert Murdoch's News International and Associated Newspapers both launched a free afternoon paper in London; News International (thelondonpaper) to compete with Associated's Metro, Associated (London Lite) to spoil the market for News International. Both papers closed down in 2009. In that year, however, the Evening Standard was converted to a free daily, thereby reintroducing competition in the UK capital. Competition in Scotland, Manchester, Liverpool and Newcastle was terminated. To some extent, diversification was successful in the UK, as the Evening Standard was published in the afternoon, while also business paper City AM has seen circulation dou- 
ble between 2005 and 2012 from 70,000 to more than 130,000. Other evening and afternoon models (thelondonpaper, London Lite, Record PM, MEN Lite) and a financial paper (FTpm) closed down.

In Ireland, Metro (by Associated Newspaper, Metro International and The Irish Times) and Herald AM (by Independent News \& Media) launched on the same day in 2005; in December 2009, they merged into Metro Herald.

\section{Conclusion}

In the Nordic countries, circulation of free dailies increased to 3.8 million in 2006 with competition in all markets. In 2013, circulation was down to 1.1 million, with a monopoly in every country. Diversification (home delivery, business papers, weekend papers, afternoon papers) failed. In the Netherlands, fierce competition ended in 2012, when publisher TMG acquired Metro and founded a free daily monopoly. Diversification (home delivery, weekend editions, quality papers) failed. Belgium had a free newspaper monopoly from the start. Diversification attempts in Germany (sports, evening, business, airline and train-delivery) failed. Also in Switzerland, diversification (household delivery, business paper) had not been successful, although the second paper in the German-speaking part was an evening paper. Austria saw the closure of local free dailies, but also growth of two competing, national papers. Luxembourg became a monopoly after diversification experiments. In the $\mathrm{UK}$, where there is competition in London and a monopoly in all other markets, diversification worked to some extent. Ireland moved from competition to monopoly.

In the 12 markets under survey, Belgium had a monopoly from the start, whereas in Germany, general free papers vanished already more than ten years ago. In six countries (Denmark, Finland, Iceland, Ireland, Luxembourg) a monopoly or near-monopoly (Sweden) was established. In Switzerland, a monopoly exists in the French and Italian parts, and an evening-morning competition in the German-speaking part. Also in London, evening and morning papers compete, in the rest of 
the country a monopoly exists. In the Netherlands, two papers from the same publisher compete. Only in Austria, a 'real' monopoly exists, with competing morning papers from different publishers.

All markets - again except Austria - show a decline in total circulation, indicating saturation. No market except Germany has seen the extinction of free dailies, and with so many monopolies, near-monopolies or half-monopolies remaining, it is likely that the 'natural' monopoly is indeed the dominant model.

Monopoly seems to be a 'natural' situation, because free newspapers tend to be perfect competitors of other free newspapers. The fact that they are handed out in public places mostly in public transport areas - means that the same people pick them up. Callius and Lithner (2007) showed for Sweden that the launch of a free daily immediately resulted in readership loss for other titles. Other ways of distribution might result in a different readership, but also in increased costs. Public transport distribution has so many advantages that it is almost impossible to avoid. It delivers a large (relatively young, professional) urban audience in a short time span, and this audience also has the time to read the paper. All other ways of distribution are much less attractive. In 2007, Danish free daily MetroXpress (public transport distribution) had 2.4 readers per copy. Competitor Nyhedsavisen (partly home-delivered) had 0.6 readers per copy.

A 'natural' monopoly is not just a theoretical concept, based on the inefficiencies of having more than one company targeting exactly the same customers, and having to build a costly infrastructure. Free newspapers can build their own distribution network, and most of them did. The similarity with classic, natural monopolies is the inability to differentiate products for different audiences. The public transport audience is the same for every publisher. As free dailies have only one source of income - advertising - a mass audience is the obvious choice. Competition will inevitably lead to lower rates. Niche markets are problematic, as they are much smaller. As general free dailies are perfect substitutes, advertising prices will decrease, especially in an economic crisis. 
The reason why there was so much competition in the first place, with up to five competing papers in some markets, was often a result of a defensive and "me-too" approach of incumbent publishers (Bakker, 2002; Picard, 2001; Vogel, 2001). In Denmark, Sweden, the UK, the Netherlands, Luxembourg, Iceland, Ireland, Switzerland and Austria, free papers were launched by incumbents to protect their advertising market, or to spoil the market for others. This created a situation in which advertising could never support all titles. Picard (1997) calculated that any new entry in the (paid) newspaper market would suffer losses for at least 10 years. Paid newspapers have a more expensive business model than free papers, but a doubling or tripling of the advertising market would be needed to support new entries - an economic decline and lower rates because of high competition would be lethal.

Diversification has not been easy, to say the least. In Germany, Luxembourg, Sweden, Denmark, Finland, the Netherlands and Ireland, all attempts failed. In Austria and Belgium, no attempts were made. In the UK and Switzerland, some evening papers survived. In Iceland, there is still home delivery and a weekend edition of the remaining paper. The only remaining free business paper is published in the financial centre of the world: London.

Economic theory has not 'predicted' a natural monopoly for free newspapers. But the failure of diversification - in content and in distribution - points in that direction, although there has been a few exceptions. There is a place for this business model for news and journalism, although it will probably not be the dominant model, and the place for the model seems rather small.

\section{REFERENCES}

Anderson, C. R. \& Zeithaml, C. P. (1984). Stage of the Product Life Cycle, Business Strategy, and Business Performance. Academy of Management Journal, 27 (1), pp. 5-24.

Bakker, P. (2002). Free Daily Newspapers; Business Models and Strategies, JMM the International Journal on Media Management 4 (3), pp. 180-187. Bakker, P. (2007). Free Daily Readership. In Worldwide Readership Research 
Symposia Vienna 2007, pp. 63-74.

Bakker, P. \& Seethaler, J. (2009). Supporting Concentration or Promoting Diversity? The Impact of Free Dailies on the Austrian Newspaper Market. In: Birgit Stark \& Melanie Magin (eds.), Die österreichische Medienlandschaft im Umbruch, pp. 67-80. Wien: Verlag der Österreichischen Akademie der Wissenschaften.

Callius, P. \& Lithner, A. (2007). Daily Reach and Beyond. In Worldwide Readership Research Symposia Vienna 2007, pp. 357-372.

Connelly, F. J. \& Daignault, G. (1974). The life cycle concept as a long term forecasting model. Journal of the Academy of Marketing Science, 2 (3), pp. 455-464.

Haas, M. (2006). Kostenlose Pendlerzeitungen in Europa. Media Perspektiven, 10, pp. 510-520.

Haller, Michael (ed.) (2009). Gratis-Tageszeitungen in den Lesermärkten Westeuropas. Nomos Verlag.

Hallin, D.C. \& Mancini, P. (2004). Comparing media system; Three models of media and politics. Cambridge; Cambridge University Press.

Harrie, E. (2009). The Nordic Media Market; Denmark - Finland - Iceland - Norway - Sweden; Media Companies and Business Activities. Gothenburg: Nordicom.

Hjarvard, S. (2007). Den politiske presse; En analyse af danske avisers politiske orientering (The political press; an analysis on political orientation of newspapers). Journalistica 5, pp. 27-53.

Holznagel, Bernd (2006). Gratiszeitungen - ein Verstoß gegen die Pressefreiheit? Befunde eines Rechtsgutachtens (Free newspapers - a threat for the freedom of the press - results of a legal procedure). Media Perspektiven, 10, pp. 529-537.

Kammer, Aske (2009). Gratisaviserne som politisk ressource (free dailies as political resource). Master thesis. Københavns Universitet.

Keiningham, T. L., Vavra, T. G., Aksoy, L. \&Wallard, H. (2005). Loyalty Myths: Hyped Strategies That Will Put You Out of Business and Proven Tactics That Really Work. John Wiley \& Sons Incorporated.

Klausch, L.T. (2007). Media brand differentiation and homogeneity in keenly competitive markets: A study of free daily newspapers in London. (MA thesis. University of London)

Klepper, S. (1996). Entry, Exit, Growth, and Innovation over the Product Life Cycle. The American Economic Review, 86, (3), pp. 562-583.

Lacy, S. \& Picard, R. (1990). Interactive monopoly power in the daily newspaper industry. Journal of Media Economics 3 (2), pp. 27-38. 
Larsson, S. (1996). The paper that took the subway to the readers. (First published in Makt \& Media, 1996). Downloaded from http://www. a4.net/artikel.asp?id=212\&eng=1

Meyer, Philip E. (2004). The Vanishing Newspaper : Saving Journalism in the Information Age. Columbia: University of Missouri Press.

Picard, R. G. (1997). Modelling the problem; de novo entry into daily newspaper markets. Newspaper Research Journal, 18 (3-4), pp. 94-108.

Picard, R. G. (2008). Shifts in Newspaper advertising expenditures and their implications for the future of newspapers. Journalism Studies, iFirst Article, pp. 1-13 [Electronic version].

Picard, R. G. (2001). Strategic Responses to Free Distribution Daily Newspapers, JMM the International Journal on Media Management, 2 (3), pp. 167-172.

Prinzing, M. (2008). (Gratis-) Pendlerzeitungen: Segen oder Fluch unseres Mediensystems? Downloaded from: http://www.gekiwo.ch/Symposium-08.45.0.html

Röper, H. (2006). Gratiszeitungen und etablierte Zeitungsverlage: (Mögliche) Effekte eines neuen Pressetyps" (Free Dailies and Incumbent Publishers: (Possible) Effects of a New Press Format), Media Perspektiven, 10, pp. 521-528.

Tlale, N.S., Bright, G., Potgieter, J., \& Xu, P. (2002). Mechatronic Modular Design of an Apparatus for PC Board Inspection. Australasian Conference on Robotics and Automation. Auckland, pp. 27-29 November.

Van Zuilen, J. (1977). The life cycle of magazines: A historical study of the decline and fall of the general interest mass audience magazine in the United States during the period 1946-1972. Graduate Press: Uithoorn (The Netherlands).

Vernon, R. (1966). International Investment and International Trade in the Product Cycle, The Quarterly Journal of Economics, 80 (2), pp. 190-207.

Vogel, A. (2001). Die tägliche Gratispresse: Ein neues Geschäftsmodell für Zeitungen in Europa (Daily Free Newspapers: A New Business Model for Newspapers in Europe), Media Perspektiven, 11, pp. 576-584.

Wadbring, I. (2003). En tidning i tiden; Metro och den svenska dagstidningsmarknaden. (A paper for its Time? Metro and the Swedish Newspaper market). Göteborg: Institutionen för Journalistik och Masskommunikation.

Wadbring, I. (2007). The Role of Free Dailies in a Segregated Society. Nordicom Review, Jubilee Issue 2007, pp. 135-147.

World Press Trends (2004-2011). Paris: World Association of Newspapers. 
PIET BAKKER, professor Cross Media \& Journalism at the School of Journalism and Communication at the Technical University Utrecht. He has edited and published books and articles on reading habits, media history, journalism, new media, Dutch media, international news, investigative journalism, the music industry, media innovation and free newspapers. He runs several blogs, for instance on the development of free newspapers at www.newspaperinnovation.com and on newspaper circulation and readership at http://paperstats.tumblr.com/.

piet.bakker@hu.nl 